\title{
Antagonism of Calcium to Aluminium-induced Chromosomal Aberra- tions in Bone Marrow Cells of Rattus norvegicus in vivo
}

\author{
Ajoy Kumar Roy, Archana Sharma and Geeta Talukder \\ Genetic Toxicology Unit, Centre of Advanced Studies in Cell and Chromosome Research, \\ Department of Botany, University of Calcutta, Calcutta 700 019, India
}

Accepted September 29, 1989

Interaction between $\mathrm{Al}$ and $\mathrm{Ca}$ is receiving increased attention following the observation that $\mathrm{Al}$ interferes with $\mathrm{Ca}$ deposition in bone (Lieberrharr et al. 1987) and calcification. $\mathrm{Al}$ interacts with citrate to form a potent inhibitor of both mineralization and growth of calcium phosphate crystals in vitro (Thomas and Meyer 1984). In the bone, $\mathrm{Al}$ is reported also to block $\mathrm{Ca}$ uptake or to be incorporated instead of Ca (Cannata et al. 1983).

In the central nervous system, CaAl silicate deposits in neurons lead to the early appearance of neurofibrillary tangles in amyotrophic lateral sclerosis/Parkinson's dementia (Gajdusek 1986). Al at concentration (75-100 $\mu \mathrm{M})$, only slightly higher than those found in body fluid competes with $\mathrm{Ca}$ and constitutes the first toxic event in the neurodegeneration process (Deleers 1985). Al is also reported to interact with the gastrointestinal Ca-transporting system (Provan and Yokel 1988).

Many reports are available on alleviation of Al toxicity in plants (Horst 1987, Roy et al. 1988), but no such reports are found in mammalian system.

Earlier work done in this laboratory has indicated the role of interaction between metals in modifying the clastogenic action, e.g. $\mathrm{Pb}$ by Se (Chakraborty et al. 1987), $\mathrm{Hg}$ by Se (Das et al. 1985), Cd by Se (Mukherjee et al. 1988). Since metals usally occur in combination, these studies are of considerable importance (Sharma and Talukder 1987).

The present work was carried out to study the alterations induced by $\mathrm{Ca}$ on the effects of $\mathrm{Al}$ in bone marrow chromosomes of Rattus norvegicus.

\section{Material and method}

Test system: 165 laboratory bred albino male rats, Rattus norvegicus, about 8-10 weeks old, weighing $120 \pm 15 \mathrm{gms}$, were maintained under standard laboratory conditions (temperature $20 \pm 3^{\circ} \mathrm{C}$, relative humidity $50 \pm 15 \%$ and photoperiod of 12 hours). Standard pellet diet (Hindustan Lever, India) and distilled water were provided ad libitum. Five animals were housed in one cage.

Test chemical: Aluminium sulphate $\left[\mathrm{Al}_{2}\left(\mathrm{SO}_{4}\right)_{3} \cdot 18 \mathrm{H}_{2} \mathrm{O}\right]$ and calcium sulphate $\left[\mathrm{CaSO}_{4}\right.$. $2 \mathrm{H}_{2} \mathrm{O}$ ] were obtained from Sarabhai M. Chemicals, India. Two concentrations ( $53 \mathrm{mg}$ and $35.4 \mathrm{mg} / 100 \mathrm{gm}$ body weight) were used. The salts were given in equal proportions.

Experimental protocol: The experiment was carried out in six different combinations, fed to the animals:
A. Distilled water (DI)
B. Salts of aluminium (Al)
C. Salts of calcium $(\mathrm{Ca})$
D. $\mathrm{Al}$ and $\mathrm{Ca}$ fed simultaneously $(\mathrm{Al}+\mathrm{Ca})$
E. Al followed by $\mathrm{Ca}$ after two hours $(\mathrm{Al} \rightarrow \mathrm{Ca})$
F. Ca followed by $\mathrm{Al}$ after two hours $(\mathrm{Ca} \rightarrow \mathrm{Al})$ 
Table showing content of different metals in $\mathrm{mg} / 100 \mathrm{gm}$ body weight

\begin{tabular}{ccccc}
\hline $\begin{array}{c}\text { Amount of } \\
\text { Al salt }\end{array}$ & $\begin{array}{c}\text { Amount of } \\
\text { Ca salt }\end{array}$ & $\begin{array}{c}\text { Amount of } \\
\mathrm{Al}\end{array}$ & $\begin{array}{c}\text { Amount of } \\
\mathrm{Ca}\end{array}$ & $\mathrm{Al}: \mathrm{Ca}$ \\
\hline 53 & 53 & 4.29 & 12.33 & $1: 2.88$ \\
35.4 & 35.4 & 2.87 & 8.23 & $1: 2.88$ \\
\hline
\end{tabular}

Aqueous solutions of the salts were administered orally to the animals daily for 21 consecutive days. In each set, 15 animals per concentration were used. Five animals were sacrificed 24 hours after days 7,14 and 21.

For chromosome studies, $0.04 \%$ colchicine was injected intra-peritoneally to the animal ( $1 \mathrm{ml}$ per $100 \mathrm{gm}$ body weight). The animal was sacrificed after 90 minutes by cervical dislocation. Marrow of femur bones was flushed out in $0.8 \%$ sodium citrate, incubated at $37^{\circ} \mathrm{C}$ for 25 minutes and fixed in $1: 3$ acetic acid: ethanol. The fixative was changed thrice after centrifugation each time and flame dried slides were prepared and stained with diluted Giemsa solution (Sharma and Sharma 1980, Preston et al. 1987).

All slides were coded and scored blind by a single person (AKR). Chromosomal aberrations were scored from 60 well-scattered metaphase plates having 42 chromosomes for each animal, making a total of 300 metaphases for each set of experiment.

Statistical analysis was carried out following analysis of variance (ANOVA) test. For multiple comparison, Duncan's new multiple range test (Kotz and Johnson 1982) was used with the help of Harter's table (Harter 1960).

\section{Results and discussion}

$\mathrm{Ca}$ is found to antagonize the toxic effects of $\mathrm{Al}$ in both doses as shown by frequency of abnormal cells (Tables 1 and 2). The frequency of metaphases with chromosomal aberrations was maximum in the animals fed aluminium alone (Set $B$ ) taking all the treatments into account. The ANOVA calculation indicates a significant difference among means at $5 \%$ level among all groups of treatment. It was most pronounced following administration of both doses of $\mathrm{Al}$ alone after 21 days of treatment, where the frequency of aberrant metaphase was significantly higher than that observed in any combination group. It indicates that $\mathrm{Ca}$ protection against $\mathrm{Al}$ is duration-dependent.

Among the three combinations $(\mathrm{Al}+\mathrm{Ca}, \mathrm{Ca} \rightarrow \mathrm{Al}$ and $\mathrm{Al} \rightarrow \mathrm{Ca}$ ), $\mathrm{Ca} \rightarrow \mathrm{Al}$ (Group F) afforded maximum protection as shown by reduction in the frequency of chromosomal abnormalities.

Since $\mathrm{Ca}$ is an essential component of life, the ability of $\mathrm{Al}^{3+}$ to replace or displace $\mathrm{Ca}$ ions has a major effect in life functions. There are conflicting reports on increase or decrease in tissue $\mathrm{Ca}$ concentration following $\mathrm{Al}$ administration, the mechanism being not clear (Mayor 1985). Al has a very high affinity for DNA, RNA and mononucleotides (Ganrot 1986) and complexes with DNA (Karlik et al. 1980, Dyrssen et al. 1987) and interacts with microtubule aggregation (Mac Donald et al. 1987). The differences in ionic radii $\left[\mathrm{Al}^{3+}\left(0.54 \mathrm{~A}^{\circ}\right), \mathrm{Ca}^{2+}\right.$ $\left.\left(1.00 \mathrm{~A}^{\circ}\right)\right]$ result in competition between $\mathrm{Al}$ and $\mathrm{Ca}$ for small molecule ligands and phosphates (Martin 1986).

In the present study, dicentrics and translocations were more frequent in combination treatments, suggesting that the effects extended over more than one cell cycle with $\mathrm{Al}$ or $\mathrm{Ca}$ alone. However, chromatid breaks and gaps were more frequent indicating renewed activity of the chemical at each cell cycle (Tables 1 and 2).

The results show that $\mathrm{Ca}$, when given in combination with $\mathrm{Al}$, counteracts the clastogenic effects of the latter. Since $\mathrm{Ca}$ administered before $\mathrm{Al}$ affords the maximum protection, it is possible that $\mathrm{Ca}^{2+}$ ions present in excess in the cell are able to prevent the action of $\mathrm{Al}^{3+}$ 
Table 1. Effect of chronic treatment of aluminium sulphate and calcium sulphate on rat bone marrow chromosomes**

\begin{tabular}{|c|c|c|c|c|c|c|c|c|}
\hline \multirow{2}{*}{$\begin{array}{l}\text { Period of } \\
\text { treatment } \\
\text { (in days) }\end{array}$} & \multirow{2}{*}{$\begin{array}{l}\text { Experi- } \\
\text { mental } \\
\text { set }\end{array}$} & \multicolumn{7}{|c|}{ Percentage of abnormalities } \\
\hline & & Gaps & Breaks & $\begin{array}{l}\text { Dicen- } \\
\text { trics }\end{array}$ & $\begin{array}{l}\text { Trans- } \\
\text { loca- } \\
\text { tions }\end{array}$ & $\begin{array}{l}\text { Pulve- } \\
\text { rized } \\
\text { cells }\end{array}$ & $\begin{array}{l}\text { Poly- } \\
\text { ploid } \\
\text { cells }\end{array}$ & $\begin{array}{c}\text { Aberrant } \\
\text { metaphase } \\
(\text { Mean } \pm \text { SEM) }\end{array}$ \\
\hline \multirow{6}{*}{7} & A & 2.00 & 1.33 & 0.33 & 0.33 & 0.33 & 0.33 & $4.67 \pm 0.82^{*}$ \\
\hline & $\mathbf{B}$ & 3.33 & 9.67 & - & 一 & 2.00 & 1.00 & $14.67 \pm 0.34$ \\
\hline & $\mathrm{C}$ & 2.67 & 5.00 & - & 1.00 & - & 0.67 & $8.67 \pm 1.00^{*}$ \\
\hline & D & 2.00 & 6.67 & 1.00 & 2.00 & 0.67 & 1.33 & $13.67 \pm 1.87$ \\
\hline & $\mathrm{E}$ & 3.67 & 7.00 & 0.67 & 0.33 & 3.67 & 0.67 & $15.00 \pm 1.58$ \\
\hline & $\mathbf{F}$ & 3.67 & 4.33 & 2.00 & 0.67 & 1.67 & 0.33 & $11.67 \pm 2.11$ \\
\hline \multirow{7}{*}{14} & A & 2.33 & 2.33 & 0.67 & 0.67 & 1.00 & 0.67 & $6.33 \pm 1.61^{*}$ \\
\hline & B & 4.00 & 10.00 & 0.33 & 1.00 & 2.00 & 2.00 & $17.33 \pm 2.21$ \\
\hline & $\mathrm{C}$ & 1.67 & 5.00 & 0.33 & 1.00 & 0.67 & 1.33 & $10.00 \pm 0.79^{*}$ \\
\hline & $\mathrm{D}$ & 4.33 & 7.33 & 1.33 & 1.33 & 2.00 & 4.00 & $20.00 \pm 3.31$ \\
\hline & $\mathrm{E}$ & 0.67 & 7.67 & 0.33 & 2.00 & 0.67 & 3.00 & $13.67 \pm 1.87$ \\
\hline & F & 3.00 & 7.00 & 2.00 & 1.00 & 1.00 & - & $12.67 \pm 2.09^{*}$ \\
\hline & A & 2.33 & 2.00 & 1.00 & 0.33 & 1.00 & 1.00 & $6.67 \pm 0.75^{*}$ \\
\hline \multirow{5}{*}{21} & B & 4.00 & 2.00 & 2.00 & 0.67 & 3.33 & 3.00 & $22.00 \pm 1.61$ \\
\hline & $\mathrm{C}$ & 1.67 & 7.00 & 0.67 & - & - & 2.33 & $10.67 \pm 1.46^{*}$ \\
\hline & $\mathrm{D}$ & 4.00 & 4.67 & 1.33 & 3.67 & 0.67 & 1.00 & $15.00 \pm 1.77^{*}$ \\
\hline & $\mathrm{E}$ & 1.67 & 4.67 & 1.67 & - & 3.00 & 2.33 & $13.00 \pm 2.00^{*}$ \\
\hline & $\mathbf{F}$ & 2.00 & 6.00 & 2.67 & 1.00 & 3.67 & 0.33 & $15.67 \pm 0.94^{*}$ \\
\hline
\end{tabular}

* $\mathrm{P} \leq \mathbf{0 . 0 5}$ as compared with Group B following ANOVA test and Duncan's multiple range test.

** Dose: Aluminium sulphate $33 \mathrm{mg} / 100 \mathrm{gm}$ body wt. (Al content $4.29 \mathrm{mg} / 100 \mathrm{gm}$ body wt.).

Calcium sulphate $53 \mathrm{mg} / 100 \mathrm{gm}$ body wt. (Ca content $12.33 \mathrm{mg} / 100 \mathrm{gm}$ body wt.).

Table 2. Effect of chronic treatment of aluminium sulphate and calcium sulphate on rat bone marrow chromosomes**

\begin{tabular}{|c|c|c|c|c|c|c|c|c|}
\hline \multirow{2}{*}{$\begin{array}{l}\text { Period of } \\
\text { treatment } \\
\text { (in days) }\end{array}$} & \multirow{2}{*}{$\begin{array}{c}\text { Experi- } \\
\text { mental } \\
\text { set }\end{array}$} & \multicolumn{7}{|c|}{ Percentage of abnormalities } \\
\hline & & Gaps & Breaks & $\begin{array}{l}\text { Dicen- } \\
\text { trics }\end{array}$ & $\begin{array}{c}\text { Trans- } \\
\text { loca- } \\
\text { tions }\end{array}$ & $\begin{array}{l}\text { Pulve- } \\
\text { rized } \\
\text { cells }\end{array}$ & $\begin{array}{l}\text { Poly- } \\
\text { ploid } \\
\text { cells }\end{array}$ & $\begin{array}{c}\text { Aberrant } \\
\text { metaphase } \\
(\text { Mean } \pm \text { SEM })\end{array}$ \\
\hline \multirow{6}{*}{7} & A & 2.00 & 1.33 & 0.33 & 0.33 & 0.33 & 0.33 & $4.67 \pm 0.82^{*}$ \\
\hline & B & 4.33 & 8.33 & 0.67 & 0.33 & 1.00 & 1.00 & $14.67 \pm 1.33$ \\
\hline & $\mathrm{C}$ & 1.00 & 5.67 & - & 0.33 & - & 1.67 & $8.67 \pm 1.00^{*}$ \\
\hline & $\mathrm{D}$ & 2.67 & 4.00 & 2.00 & 0.67 & 1.67 & - & $10.67 \pm 0.94$ \\
\hline & $\mathrm{E}$ & 1.67 & 3.67 & 2.67 & 1.00 & - & 1.67 & $10.00 \pm 0.79$ \\
\hline & $\mathrm{F}$ & 1.00 & 7.00 & 2.00 & 2.00 & 1.00 & 1.00 & $10.67 \pm 3.40$ \\
\hline \multirow{7}{*}{14} & A & 2.33 & 2.33 & 0.67 & 0.67 & 1.00 & 0.67 & $6.33 \pm 1.61^{*}$ \\
\hline & B & 4.00 & 4.67 & 0.67 & 1.00 & 2.67 & 5.33 & $17.33 \pm 1.94$ \\
\hline & $\mathrm{C}$ & 2.00 & 2.00 & 1.00 & - & 1.00 & 2.33 & $8.33 \pm 1.27^{*}$ \\
\hline & D & 2.67 & 6.67 & 1.33 & 1.67 & 0.67 & 4.00 & $15.67 \pm 3.10$ \\
\hline & $\mathrm{E}$ & 5.67 & 9.33 & 0.67 & 1.00 & 0.67 & 0.33 & $16.00 \pm 1.00$ \\
\hline & $\mathrm{F}$ & 3.33 & 10.33 & 0.67 & 2.67 & 2.67 & 0.67 & $16.67 \pm 0.91$ \\
\hline & A & 2.33 & 2.00 & 1.00 & 0.33 & 1.00 & 1.00 & $6.67 \pm 0.75^{*}$ \\
\hline \multirow{5}{*}{21} & $\mathbf{B}$ & 2.33 & 6.67 & 2.33 & 1.33 & 2.00 & 3.33 & $17.67 \pm 1.00$ \\
\hline & $\mathrm{C}$ & 1.00 & 7.67 & 1.00 & 0.33 & 1.00 & 2.33 & $13.00 \pm 0.92^{*}$ \\
\hline & D & 4.33 & 6.67 & 1.67 & 2.00 & 1.00 & - & $14.00 \pm 0.61^{*}$ \\
\hline & $\mathrm{E}$ & 2.00 & 4.33 & - & 3.33 & 0.67 & 1.67 & $12.00 \pm 1.61^{*}$ \\
\hline & $\mathrm{F}$ & 1.00 & 7.00 & 2.00 & 2.00 & 1.00 & 1.00 & $14.00 \pm 1.70^{*}$ \\
\hline
\end{tabular}

* $\mathbf{P} \leq 0.05$ as compared with Group B following ANOVA test and Duncan's multiple range test.

** Dose: Aluminium sulphate $35.4 \mathrm{mg} / 100 \mathrm{gm}$ body wt. (Al content $2.87 \mathrm{mg} / 100 \mathrm{gm}$ body wt.).

Calcium sulphate $35.4 \mathrm{mg} / 100 \mathrm{gm}$ body wt. (Ca content $8.23 \mathrm{mg} / 100 \mathrm{gm}$ body wt.). 
ions on chromosomal proteins and spindle microtubules. This point is further strengthened by the observation that after 21 days of treatment, $\mathrm{Ca}$ in all combination significantly reduced the percentage of aberrant metaphases (Tables 1 and 2).

\section{Summary}

The interaction of $\mathrm{Al}$ with $\mathrm{Ca}$ in six different combinations was studied in bone marrow chromosomes following daily oral administration for prolonged periods. Cytotoxic effects of $\mathrm{Al}$, measured by the induction of chromosomal aberrations, were countered by treatment with $\mathrm{Ca}$. The protection afforded was maximum when $\mathrm{Ca}$ was fed at a ratio of $3: 1$, as related to $\mathrm{Al}, 2$ hours before the administration of $\mathrm{Al}$.

\section{Acknowledgments}

The authors are grateful to Professor A. K. Sharma, Programme Co-ordinator, Centre for Advanced Studies, for the laboratory facilities provided and the University Grants Commission, New Delhi and Council for Scientific and Industrial Research, New Delhi for financial assistance.

\section{References}

Cannata, J. B., Briggs, J. D., Junor, B. J. R., Fell, G. S. and Beastall, G. 1983. Effect of acute aluminium overload on calcium and parathyroid hormone metabolism. Lancet 1: 501-503.

Chakraborty, I., Sharma, A. and Talukder, G. 1987. Antagonistic and synergistic effects of lead and selenium in Rattus norvegicus. Toxicol. Lett. 37: 21-26.

Das, S. K., Giri, A. K., Sharma, A. and Talukder, G. 1985. Effects of mercury selenium antagonism on mammalian cell division. Cytobios 42: 271-277.

Deleers, M. 1985. Cationic atmosphere and cation competition binding at negatively charged membranes: Pathological implications of aluminum. Res. Commun. Chem. Pathol. and Pharmacol. 49: 277293.

Dyrssen, D., Haraldsson, C., Nyberg, E. and Wedborg, M. 1987. Complexation of aluminum with DNA. J. Inorg. Biochem. 29: 67-75.

Gajdusek, D. C. 1986. Calcium aluminium silicon deposits in neurons lead to paired helical filaments identical to those of $\mathrm{AD}$ and Down's patients. Neurobiol. Aging 7 (6): 555-556.

Ganrot, P. O. 1986. Metabolism and possible health effects of aluminium. Environ. Health Perspect. 65: $363-441$.

Harter, H. L. 1960. Critical values for Duncan's new multiple range test. Biometrics 16: 671-685.

Horst, W. J. 1987. Aluminum tolerance and calcium efficiency of cowpea genotypes. J. Plant Nutr. 10: 1121-1129.

Karlik, S. J., Eichhorn, G. L., Lewis, P. N. and Crapper, D. R. 1980. Interaction of aluminum species with deoxyribonucleic acid. Biochemistry 19: 5991-5998.

Kotz, S. and Johnson, N. L. (Eds.) 1982. Encyclopedia of Statistical Sciences. Vol. 2. Wiley, New York, pp. 424-425.

Lieberrharr, M., Grosse, B., Curnot-Witmer, G., Hermann-Erlee, M. P. M. and Balsam, S. 1987. Aluminium action on mouse bone cell metabolism and response to PTH and 1,25-dihydroxy-vitamin $\mathbf{D}_{3}$. Kidney Int. 31: 736-743.

Mac Donald, T. L., Humphreys, W. C. and Martin, R. B. 1987. Promotion of tubulin assembly by aluminium ion in vitro. Science 236: 183-186.

Martin, R. B. 1986. The chemistry of aluminium as related to biology and medicine. Clin. Chem. 32 (10): 1797-1806.

Mayor, G. H. 1985. The case for parathyroid hormone. Am. J. Kidney Diseases 6 (5): 306-308.

Mukherjee, A., Sharma, A. and Talukder, G. 1988. Effect of selenium on cadmium-induced chromosomal aberrations in bone marrow cells of mice. Toxicol. Lett. 41: 23-29.

Preston, R. J., Dean, B. J., Galloway, S., Holden, H., McFee, A. F. and Shelby, M. 1987. Mammalian in 
vivo cytogenetic assays. Analysis of chromosome aberrations in bone marrow cells. Mutat. Res. 189: $157-165$.

Provan, S. D. and Yokel, R. A. 1988. Influence of calcium on aluminium accumulation by the rat jejunal slice. Res. Commun. Chem. Pathol. Pharmacol. 59: 79-92.

Roy, A. K., Sharma, A. and Talukder, G. 1988. Some aspects of aluminium toxicity in plants. Bot. Rev. 54: $145-178$.

Sharma, A. and Talukder, G. 1987. Effects of metals on chromosomes of higher organisms. Environ. Mutagen. 9: 191-226.

Sharma, A. K. and Sharma, A. 1980. Chromosome Techniques-Theory and Practice. 3rd ed. Butterworths and Co., U. K.

Thomas, W. C. and Meyer, J. L. 1984. Aluminium-induced osteomalacia: an explosion. Am. J. Nephrol. 4: 201-203. 